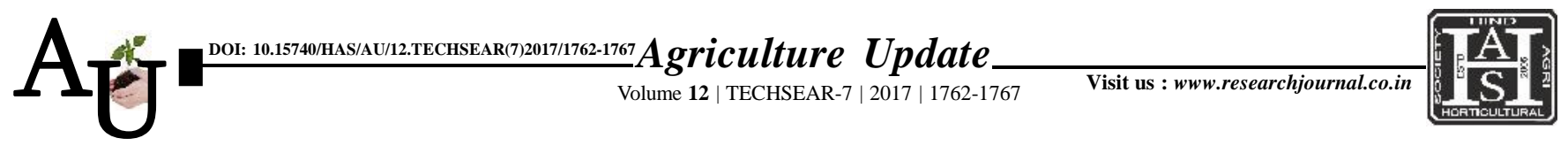

\title{
Research Article: Study on distribution and occurrence of phototropic insect pest fauna of vetiver [Vetiveria zizanioides (L) Nash] ecosystem
}

Article Chronicle : Received :

19.07.2017;

Accepted :

03.08.2017

KEY WoRds:

Distribution,

Occurrence,Phototropic, Insect pest, Vetiver, Light trap

\section{AMIT KUMAR SHARMA, RISHIKESH MANDLOI AND R. PACHORI}

SUMMARY : The present study was conducted to study of scope of light trap as IPM tool in Vetiver ecosystem in Balaghat region of Madhya Pradesh. Information on insect pest fauna of Vetiver ecosystem collected in light trap was documented. Data of trap catch during the year 2006 (Kharif season) was classified on taxonomic basis and economic aspect (crop pests). A total of 42 insect pest species were recorded. These insect pest species belongs to 5 orders and 22 families. Lepidoptera was the largest order with 24 species.Other orders were Hemiptera ( 9 species), Coleoptera (4 species) and Orthoptera (4 species) and Isopterawith single species only. Among these phototropic insect pests 16 species were recorded as major and minor pests of vetiver (viz., Chillo partulus S., Spodoptera litura Fab., Mythimna separata C., Sesamia inferens Wal, Scirpophaganivella Fab., Tryporyza sp.,Nephotettix sp., Leptocorisa sp.,Cletus punctiger (Dallas), Aulacophora fovecollis L., Holotrichia insularis B., Mylobris pustulata T., Trilophidia cristella S., Gastrimargus transversus T., Gryllus sp., Microtermes obesi Hol.). The season's trap catch collection also includedthe phototropic insect pests of Medicinal crops (15), Paddy (14) Polyphagous (6), Pulses (7), Cereals (6), Oilseeds (5), Sugarcane (4), Fodder crops (8) and Forest trees and others (7). The present study reviled the valuable documented information on distribution and occurrence of phototropic insect pest species of vetiver. It also gives broader scope of using light trap as Integrated Pest Management tool against these pest species of vetiver and medicinal crops as light trap can overcome the problem linked to the use of insecticides and cementing the strength of medicinal crops as potential therapeutic mile stone.

How to cite this article : Sharma, Amit Kumar, Mandloi, Rishikesh and Pachori, R. (2017). Study on distribution and occurrence of phototropic insect pest fauna of vetiver [Vetiveria zizanioides (L) Nash] ecosystem. Agric. Update, 12(TECHSEAR-7) : 1762-1767; DOI: 10.15740/HAS/AU/12.TECHSEAR(7)2017/1762-1767.
Author for correspondence :

\section{AMIT KUMAR SHARMA}

Department of

Entomology, College of

Agriculture, Jawahar Lal

Nehru Krishi

Viswavidyalaya, JABALPUR (M.P.) INDIA

See end of the article for authors' affiliations 